Wojciech Kwiatkowski ${ }^{1}$

\title{
POZYCJA W SYSTEMIE WŁADZY USA ORAZ ZADANIA RADY DS. MONITOROWANIA STABILNOŚCI FINANSOWEJ
}

\section{Wprowadzenie}

Zapoczątkowany w 2007 r. globalny kryzys finansowy wymusił całkowicie nowe spojrzenie polityków w wielu państwach na kwestie nadzoru i regulacji krajowego systemu finansowego oraz nadzoru transgranicznego. Z gruntowną reorganizacją porządku prawnego w tej kwestii zmierzyć się musiały także Stany Zjednoczone. Choć „uzdrowienie” sektora finansowego postrzegano jako ponadpartyjne zadanie wszystkich sił politycznych w USA ${ }^{2}$, to do zaprzysiężenia nowego prezydenta w styczniu 2009 r. podejmowano de facto doraźne środki mające na celu przysłowiowe „gaszenie pożarów”3. Dopiero w grudniu 2009 r. kongresman Barney Frank i senator Chris Dodd przedstawili projekt ustawy mającej w sposób kompleksowy zabezpieczyć kraj przed podobnymi scenariuszami w przyszłości ${ }^{4}$ Kluczowym jej postanowieniem było utworzenie Rady ds. Monitorowania Stabilności Finansowej (Financial Stability Oversight Council - FSOC) jako organu odpowiedzialnego za identyfikację potencjalnych źródeł zagrożenia (zarówno wewnętrznych, jak i zewnętrznych) dla stabilności całego sektora finansowego w USA. Mając na uwadze złożoność systemu finansowego USA i kreatywność kadry zarządzającej instytucjami finansowymi na amerykańskim rynku, można zaryzykować twierdzenie, że utworzenie tego

1 Dr Wojciech Kwiatkowski, Katedra Amerykanistyki, Wydział Prawa i Administracji, Uniwersytet Kardynała Stefana Wyszyńskiego.

2 Reakcja władz federalnych na kryzys zbiegła się z innymi istotnymi wydarzeniami w tym kraju, jak gwałtownie rosnący wzrost (federalnego) długu publicznego, utrata w styczniu $2007 \mathrm{r}$. przez partię urzędującego wówczas prezydenta większości w Kongresie oraz kampania wyborcza do federalnych ośrodków władzy w listopadzie $2008 \mathrm{r}$.

3 Za najważniejszy akt prawny przyjęty należy uznać tzw. ustawę Paulsona z 2008 r. (Emergency Economic Stabilization Act of 2008, Pub. L. 110-343).

4 Dodd-Frank Wall Street Reform and Consumer Protection Act of 2010, Pub. L. 111-203. 
organu, choć wygodne ze względów politycznych ${ }^{5}$, było przede wszystkim czynnością porządkującą i scalającą nadzór nad systemem finansowym w $\mathrm{USA}^{6}$ oraz dostosowującą go do nowych wyzwań. Niniejszy artykuł ma na celu wykazanie, że przyznanie Radzie dwóch istotnych, acz wysoce kontrowersyjnych w wolnorynkowej gospodarce amerykańskiej, narzędzi (tj. możliwości objęcia wzmożonym nadzorem systemowo ważnej instytucji finansowej oraz możliwości wszczęcia procedury kontrolowanej likwidacji przedsiębiorstwa finansowego) nie spowodowało nadmiernej ingerencji organów władzy w swobodę działalności gospodarczej, a jedynie przyczyniło się do większej dyscypliny finansowej podmiotów sektora finansowego prowadzących swoją działalność biznesową na terytorium USA.

\section{Architektura nadzoru nad systemem finansowym w USA}

To, z jak złożoną materią ${ }^{7}$ ma do czynienia amerykański federalny ustawodawca w kwestiach związanych $\mathrm{z}$ regulowaniem i nadzorem nad systemem finansowym, najlepiej pokazują dwie jego cechy. Pierwszą jest istotny udział w amerykańskim rynku (zwłaszcza w sektorze bankowym i ubezpieczeniowym) podmiotów działających jedynie na podstawie prawa stanowego i uzyskanej od władz stanowych licencji. W konsekwencji również nadzór jest w tym wypadku wykonywany niemalże wyłącznie przez stosowne podmioty stanowe ${ }^{8}$. Drugą cechą systemu finansowego USA jest,

5 Stany Zjednoczone są krajem, w którym przebiega niemalże ustawiczna kampania wyborcza na różnych szczeblach władzy. Stąd utworzenie FSOC - jako organu składającego się w dużej mierze ze specjalistów niebędących czynnymi politykami - można postrzegać jako próbę uchylenia się - zarówno Kongresu, jak i prezydenta oraz podległych mu urzędników - od stanowienia prawa i podejmowania decyzji w wielu wypadkach koniecznych czy wręcz niezbędnych do prawidłowego funkcjonowania państwa, ale „niewygodnych" i ryzykownych politycznie.

6 Przy okazji utworzenia Rady ustawa powołała do życia dwie instytucje, Biuro Badań Naukowych (Office of Financial Research) oraz - ulokowany w ramach Systemu Rezerwy Federalnej, lecz całkowicie niezależny od Rady Gubernatorów SRF - Urząd Finansowej Ochrony Konsumentów (Consumer Financial Protection Bureau - CFPB). W artykule została pominięta bardzo ciekawa kwestia oceny rozwiązań prawnych dotyczących drugiego z organów, natomiast z całą pewnością zasługuje ona na pogłębioną analizę w osobnym opracowaniu.

7 Zob. np. A. Mika, Przedkryzysowa architektura nadzorczo-regulacyjna w USA jako katalizator kryzysu subprime, „Bezpieczny Bank” 2012, nr 4(49), s. 7-23. Zob. też W. Kwiatkowski, System Rezerwy Federalnej, Wydawnictwo Naukowe Scholar, Warszawa 2014, s. 68-69.

8 Zob. K.W. Dam, The Subprime Crisis and Financial Regulation: International and Comparative Perspectives, „John M. Olin Law \& Economics Working Paper” 2010, No. 517, s. 10. Warto dodać, że blisko 70\% banków w USA działa właśnie na podstawie stanowej licencji i podlega nadzorowi ze strony stosownych stanowych organów oraz że dużą część kredytów subprime (które w dużej mierze przyczyniły się do kryzysu z 2007 r.) udzieliły właśnie takie podmioty. Zob. A. Sławiński, Przyczyny globalnego kryzysu bankowego, 
będący następstwem ustawodawstwa $\mathrm{z}$ lat 30. i 50. XX w. ${ }^{9}$, mocno zaznaczony podział na sektory bankowy, ubezpieczeniowy i inwestycyjny. W rezultacie regulacja i nadzór nad poszczególnymi sektorami również zostały powierzone kilku niezależnym od siebie podmiotom, przy czym ich wzajemne kompetencje regulacyjne i nadzorcze albo się pokrywały, albo wręcz przeciwnie - stwarzały dające się wykorzystać luki ${ }^{10}$. Całość jednak nie doczekała się gruntownej nowelizacji wraz z deregulacją sektora finansowego w USA $\mathrm{z}$ lat 90 . XX w. ${ }^{11}$

Obecnie do nadzoru nad systemem finansowym w USA upoważnionych jest wiele podmiotów, jednak kluczowymi są: System Rezerwy Federalnej (Federal Reserve System - FRS), Urząd Kontrolera Waluty (Office of the Comptroller of the Currency - OCC), Federalna Korporacja Ubezpieczająca Depozyty (Federal Deposit Insurance Corporation - FDIC), Komisja Papierów Wartościowych i Giełd (U.S. Securities and Exchange Commission - SEC), Federalne Biuro ds. Nadzoru nad Sektorem Ubezpieczeniowym (Federal Insurance Office - FIO), Administracja Krajowych Unii Kredytowych (National Credit Union Administration - NCUA) oraz Komisja ds. Rynku Kontaktów Terminowych (Commodity Futures Trading Commission - CFTC). Nadzór ten uzupełniany jest przez stanowe organy nadzorcze (w zakresie sektora bankowego oraz ubezpieczeniowego organy takie działają w 50 stanach i na trzech terytoriach zależnych USA) oraz różnego rodzaju podmioty działające z woli stanów (jak choćby Krajowe Stowarzyszenie Komisarzy Ubezpieczeniowych), których zadaniem jest dążenie do unifikacji stanowych regulacji prawnych dotyczących danego sektora oraz koordynacja nadzoru nad nim.

w: Nauki społeczne wobec kryzysu na rynkach finansowych, red. J. Osiński, S. Sztaba, Oficyna Wydawnicza SGH, Warszawa 2009, s. 47.

9 Chodzi tu zwłaszcza o ustawy Banking Act, Glass-Steagall Act 1933, Pub. L. 73-66 oraz Bank Holding Company Act 1956, Pub. L. 84-511. Zob. też W. Kwiatkowski, op.cit., s. 68-69.

10 By ograniczyć to zjawisko, w 1978 r. uchwalono ustawę o Federalnej Radzie ds. Nadzorowania Instytucji Finansowych (Federal Financial Institutions Examination Council), w której skład weszli przedstawiciele kluczowych federalnych organów regulacyjno-nadzorczych (a od 2006r. do grupy włączono także przedstawicieli stosownych organów stanowych). Do zadań Rady należy stworzenie zasad opracowywania raportów, a także przeprowadzania i wzajemnego uznawania wyników kontroli. Efektem prac Rady jest też utworzenie jednolitego systemu szkoleń nadzorców i systemu regulacji ostrożnościowych oraz wspólnego dla wszystkich podmiotów nadzorujących systemu ratingowego dla banków komercyjnych.

11 Chodzi tu o Riegle-Neal Act Interstate Banking and Branching Efficiency Act of 1994, Pub. L. 103-328 oraz Financial Services Modernization Act of 1999, Pub. L.106-102. Szerzej F. Mishkin, Ekonomika pieniqdza, bankowości i rynków finansowych, PWN, Warszawa 2002, s. 345, 393; W. Kwiatkowski, op.cit., s. 73. 


\section{Skład i cele Rady ds. Monitorowania Stabilności Finansowej}

W skład Rady ds. Monitorowania Stabilności Finansowej wchodzi ex officio 15 osób reprezentujących określone w ustawie instytucje, z których większość wykonuje zadania regulacyjne i nadzorcze nad określoną częścią sektora finansowego w USA. Ustawa wprowadza podział członków Rady na tych, którzy mają prawo do uczestniczenia w spotkaniach i głosowania ${ }^{12}$, oraz tych, którzy uczestniczą w zebraniach Rady, ale nie posiadają prawa głosu ${ }^{13}$. Ta druga kategoria członków - w drodze decyzji przewodniczącego Rady - może zostać wykluczona z konkretnego posiedzenia. Z prawem do głosowania w Radzie uczestniczą:

- sekretarz skarbu (jako przewodniczący Rady) ${ }^{14}$,

- przewodniczący Rady Gubernatorów Systemu Rezerwy Federalnej ${ }^{15}$,

- przewodniczący Federalnej Korporacji Ubezpieczającej Depozyty ${ }^{16}$,

- Kontroler Waluty (jako kierownik Urzędu Kontrolera Waluty) ${ }^{17}$,

- przewodniczący Komisji Papierów Wartościowych i Giełd ${ }^{18}$,

1212 U.S. Code $\$ 5321(\mathrm{~b})(1)$.

1312 U.S. Code $\$ 5321(\mathrm{~b})(2)$.

14 Sekretarz skarbu USA jest powoływany przez prezydenta za radą i zgodą Senatu USA. Zasadniczo pełni on swoje obowiązki tak długo, jak chce tego prezydent.

15 System Rezerwy Federalnej pełni funkcję banku centralnego USA. Pomijając operacje na otwartym rynku, jądrem tego organu jest Rada Gubernatorów. Oprócz wykonywania nadzoru nad określonymi podmiotami do zadań banku należy m.in. kształtowanie i realizacja polityki pieniężnej, zapewnienie obsługi finansowej instytucji depozytowych oraz bezpieczeństwa i wiarygodności systemu płatniczego, wprowadzanie gotówki i bilonu do obiegu, a także pełnienie funkcji banku państwa. Na czele Rady stoi przewodniczący, który wybierany jest na cztery lata z grona jej członków przez prezydenta - za zgodą Senatu.

16 Federalna Korporacja Ubezpieczająca Depozyty jest instytucją zapewniającą system gwarantowania depozytów bankowych złożonych w bankach federalnych, stanowych przynależących do FRS oraz stanowych nieprzynależących do FRS, ale dobrowolnie w niej ubezpieczonych (obecnie wysokość sumy gwarantowanej wkładów indywidualnych gwarantowana jest przez FDIC wynosi 250 tys. USD). Sprawuje też nadzór nad bankami ubezpieczonymi w FDIC, posiadającymi licencję stanową i niebędącymi członkami FRS (non-member commercial banks). Korporacją kieruje pięcioosobowy zarząd, na którego czele stoi przewodniczący wybierany na pięcioletnią kadencję przez prezydenta za zgodą Senatu.

17 Urząd Kontrolera Waluty wydaje licencje federalne upoważniające do założenia banku, zatwierdza zezwolenia na zakładanie oddziałów przez banki (w tym oddziały zagraniczne banków krajowych oraz oddziały banków zagranicznych na terytorium USA), określa zasady łączenia i przekształcania banków, przyjmuje także od banków narodowych kwartalne sprawozdania z ich stanu i dochodów. W sytuacji wykrycia nieprawidłowości Urząd może wydawać nakazy i zakazy określonego działania, zażądać usunięcia poszczególnych pracowników banku oraz nakładać kary pieniężne na konkretne osoby. Na czele tej instytucji stoi Kontroler Waluty powoływany przez prezydenta za zgodą Senatu na pięć lat.

18 Komisja Papierów Wartościowych i Giełd zajmuje się egzekucją federalnego prawa dotyczącego obrotu papierami wartościowymi oraz regulowaniem i kontrolowaniem rynku papierów wartościowych, sprawuje też nadzór nad firmami zajmującymi się obrotem papierami wartościowymi oraz bankami inwestycyjnymi, doradcami inwestycyjnymi i brokerami. Jej pracami kieruje pięcioosobowy zarząd, którego członkowie 
- dyrektor Urzędu Finansowej Ochrony Konsumentów (CFPB) ${ }^{19}$,

- przewodniczący Krajowej Administracji Unii Kredytowych ${ }^{20}$,

- $\quad$ szef Komisji ds. Obrotu Giełdowymi Kontraktami Terminowymi ${ }^{21}$,

- dyrektor Federalnej Agencji ds. Finansowania Mieszkalnictwa (FHFA) ${ }^{22}$,

- powoływany przez prezydenta za zgodą Senatu na sześć lat ekspert ubezpieczeniowy. Natomiast członkami Rady bez prawa do głosowania zostali:

- pełniący swoje obowiązki przez dwa lata przedstawiciele reprezentujący zrzeszenia stanowych organów kontroli sektorów ubezpieczeniowego, bankowego, papierów wartościowych (łącznie trzy osoby, po jednym przedstawicielu dla każdego sektora),

- po jednej osobie reprezentującej organy afiliowane przy Departamencie Skarbu, których zadaniem jest wspieranie prac Rady, tj.:

- Biuro Badań Naukowych (Office of Financial Research - OFR) reprezentowane przez dyrektora powoływanego przez prezydenta z zgodą Senatu,

- Federalne Biuro ds. Nadzoru nad Sektorem Ubezpieczeniowym reprezentowane przez dyrektora powoływanego przez sekretarza skarbu.

Z kilkoma wyjątkami, gdzie wymagana jest kwalifikowana większość 2/3, Rada podejmuje decyzje większością głosów. Warto zauważyć, że ustawa w sposób szczególny statuuje osobę o stricte politycznym rodowodzie i jednocześnie całkowicie podległą służbowo prezydentowi, tj. sekretarza skarbu. Oprócz przewodniczenia ex officio obradom Rady ma on też możliwość zwoływania posiedzeń poza ustawowym bądź określonym wcześniej przez członków Rady harmonogramem zawsze wtedy, gdy uzna to za stosowne. On też określa porządek posiedzenia i może decydować o wykluczeniu członka FSOC bez prawa głosu z konkretnego posiedzenia ${ }^{23}$. To on

wybierani są przez prezydenta za zgodą Senatu na pięć lat. Z grona zarządu prezydent wskazuje przewodniczącego Komisji.

19 Urząd Finansowej Ochrony Konsumentów funkcjonuje w ramach FRS, ale cieszy się dużą autonomią (w tym finansową) w strukturze banku. Zadania Urzędu skupiają się wokół regulacji i nadzoru nad sektorem finansowym w USA w zakresie ochrony konsumentów korzystających z dóbr oferowanych przez ten sektor. Urzędem kieruje (jednoosobowo) przewodniczący powoływany na pięć lat przez prezydenta za zgodą Senatu.

20 Krajowa Administracja Unii Kredytowych jest kierowana przez trzyosobowy zarząd (na którego czele stoi przewodniczący wybierany przez prezydenta). Do jej zadań należy nadzór i regulowanie działania unii kredytowych działających na podstawie prawa federalnego.

21 Komisja ds. Obrotu Giełdowymi Kontraktami Terminowymi została utworzona w 1975 r. Kieruje nią pięcioosobowy zarząd wybierany przez prezydenta za zgodą Senatu na pięć lat. Na czele zarządu stoi przewodniczący wybierany ze składu zarządu przez prezydenta. Zadaniem Komisji jest regulacja rynku opcji i kontaktów terminowych.

22 Federalna Agencja ds. Finansowania Mieszkalnictwa sprawuje nadzór nad instytucjami wspomagającymi udostępnianie funduszy instytucjom udzielającym kredytów hipotecznych. Kieruje nią dyrektor powoływany na pięć lat przez prezydenta za zgodą Senatu.

2312 U.S. Code $\$ 5321$ (b)(3). 
zdaje też coroczny raport z pracy Rady stosownym komisjom obu izb Kongresu ${ }^{24}$. O jego dominującej pozycji decyduje również to, że choć Rada większością $2 / 3$ osób upoważnionych do głosowania decyduje o uznaniu niebankowych spółek finansowych za istotne z punktu widzenia stabilności sektora finansowego w USA (patrz dalsza część), to w grupie osób głosujących za tym wnioskiem musi być sekretarz skarbu (można zatem zaryzykować twierdzenie, że przysługuje mu swoiste „weto" w stosunku do decyzji Rady). Podobnie sytuacja wygląda wówczas, gdy Rada chce znieść swoją własną wcześniejszą decyzję w tej materii. Warto też dodać, że to sekretarz skarbu, wraz z przewodniczącym Rady Gubernatorów FRS, negocjuje z podmiotami zewnętrznymi kwestię nadzoru transgranicznego i wymianę informacji pomiędzy instytucjami nadzorującymi.

Ustawodawca amerykański wyznaczył Radzie kilka celów, przy czym nie wskazał, który z nich będzie najważniejszy. Są to:

1) identyfikacja tych obszarów ryzyka, które mogą wpłynąć na stabilność całego sektora finansowego USA (przy czym samo ryzyko może mieć źródło zarówno na terytorium USA, jak i poza granicami państwa amerykańskiego);

2) promowanie dyscypliny rynkowej oraz wyszukiwanie luk w obecnych regulacjach, pozwalających na wystąpienie ryzyka w przyszłości;

3) planowanie skoordynowanej odpowiedzi na te zagrożenia.

Rada ma obowiązek odbycia czterech spotkań w roku, w praktyce odbywają się one częściej. Bieżące działania podejmowane przez nią skupiają się na monitowaniu funkcjonowania uczestników systemu finansowego USA pod kątem możliwości wystąpienia z ich strony zagrożenia dla stabilności systemu finansowego oraz koordynacji wymiany danych pomiędzy tymi instytucjami, które zajmują się regulacją i nadzorem sektora finansowego USA ( $\mathrm{w}$ tym także stosownymi podmiotami stanowymi). W sytuacji, w której zadecyduje ona (większością 2/3 głosów) o uznaniu niebankowych spółek finansowych ${ }^{25} \mathrm{za}$ istotne z punktu widzenia stabilności sektora finansowego w USA, spółki te będą podlegały dodatkowym mechanizmom kontrolnym ze strony stosownych organów, a w sytuacji problemów z płynnością - będą mogły zostać zreorganizowane bądź zlikwidowane w specjalnej, odrębnej od prawa

24 W Senacie jest to Komisja ds. Bankowości, Mieszkalnictwa i Urbanistyki (Committee on Banking, Housing, and Urban Affairs of the Senate), w Izbie Reprezentantów natomiast Komisja Bankowości i Usług Finansowych (Committee on Banking and Financial Services of the House of Representatives).

${ }_{25}$ Za takie uważa się zasadniczo instytucje finansowe, które oferują kapitał, ale nie są stricte bankami działającymi na podstawie stosownej licencji i nie pozyskują środków ze zgromadzonych depozytów swoich klientów. W sytuacji niewypłacalności podmioty te podlegają normalnej procedurze upadłościowej przeprowadzanej przez sąd upadłościowy na podstawie federalnego prawa upadłościowego. Jako niebanki w sytuacji utraty płynności finansowej nie mają także dostępu do okna dyskontowego oferowanego przez bank centralny. 
upadłościowego procedurze. Ponadto, w myśl sekcji 804 ustawy Dodda-Franka, Rada zajmuje się też identyfikacją szczególnie istotnych z punktu widzenia stabilności systemu finansowego USA instytucji zarządzających infrastrukturą rynku finansowego (służącą rozliczaniu płatności, obrotu papierami papierów wartościowymi i instrumentami pochodnymi) i w ramach tego może zlecić wydanie konkretnych regulacji przez odpowiednio: SRF, SEC i CFTC ${ }^{26}$. Rada może też zlecić - zarówno organom wchodzącym w jej skład, jak i podległemu jej Biuru Badań Naukowych - przeprowadzenie określonych dalszych badań i analiz, zwłaszcza w odniesieniu do materiałów pozyskanych od stanowych organów nadzoru.

\section{System Rezerwy Federalnej a „systemowo ważne instytucje finansowe"}

Ustawa Dodda-Franka znacząco rozszerzyła uprawnienia nadzorcze banku centralnego USA w porównaniu ze stanem sprzed 2010 r. Przede wszystkim te banki, których kapitalizacja przekracza 50 mld USD ${ }^{27}$, zostały ex lege uznane za „systemowo ważne" i jako takie objęto je szczególnym nadzorem ze strony banku centralnego. FSOC została natomiast upoważniona do identyfikacji tych instytucji finansowych, które nie zostały objęte szczególnym nadzorem z mocy ustawy (bo nie są stricte bankami), ale rozkład ich aktywów i powiązania biznesowe są tego typu, że ich niekontrolowany upadek bądź procedura upadłościowa prowadzona w standardowy sposób (na podstawie federalnego prawa upadłościowego) mogłyby negatywnie wpłynąć na stabilność całego sektora finansowego USA. Jeżeli FSOC uzna jakiś podmiot za „systemowo ważny”, wówczas zleca FRS dokonywanie wzmożonego nadzoru nad nim ${ }^{28}$ na takich samych zasadach, jakie dotyczą podmiotów automatycznie objętych wzmożonym nadzorem. Ponieważ włączenie takiego podmiotu do grona „podlegających wzmożonej kontroli” wiąże się dla niego z pewnymi obciążeniami

26 W 2012 r. Rada ostatecznie uznała osiem instytucji zapewniających funkcjonowanie infrastruktury rynku finansowego za ważne z punktu widzenia stabilności całego systemu finansowego USA. Zob. Financial Stability Oversight Council Annual Report 2012, Washington 2012, s. 119-120, 145. Materiał dostępny na stronie: http://www.treasury.gov/initiatives/fsoc/studies-reports/Pages/2012-Annual-Report.aspx [dostęp 12.10.2016].

27 W myśl przyjętych w ustawie Dodda-Franka rozwiązań holdingi bankowe o aktywach przekraczających 50 mld USD stały się ex lege „systemowo ważne” i jako takie „z automatu” zostały objęte zainteresowaniem FSOC.

28 Na zalecenie FSOC lub z własnej inicjatywy Rada Gubernatorów FRS może ustanowić różne standardy dla poszczególnych istotnych systemowo instytucji (na podstawie określonych czynników związanych z ryzykiem). 
(np. z obowiązkiem poddania się corocznym strestestom ${ }^{29}$ ), w myśl sekcji 113 ustawy Dodda-Franka - przed uznaniem go za systemowo ważny - Rada musi wziąć pod uwagę szereg czynników, jak np. jego znaczenie jako źródła kredytu dla gospodarstw domowych bądź przedsiębiorstw i jego znaczenie jako źródła płynności dla systemu finansowego USA, a także rodzaj, charakter i wielkość zaciągniętych zobowiązań. FSOC może też wydać stosowne rekomendacje dla Rady Gubernatorów FRS, by ta wprowadziła wyższe wymogi adekwatności kapitałowej, oceny ryzyka czy też określiła limity koncentracji kapitału (sekcja 115 ustawy). Ponadto, w myśl sekcji 121 ustawy Rada (większością 2/3) może postanowić o tym, by objęte wzmożonym nadzorem podmioty podlegały dalszym ograniczeniom, jak np.:

- ograniczenie zdolności takiego podmiotu do zakupu, przejęcia lub konsolidacji z innym podmiotem,

- ograniczenie praw takiego podmiotu w oferowaniu określonych produktów finansowych,

- zażądanie od takiego podmiotu zaprzestania określonej działalności,

- wprowadzenie dodatkowych warunków, na jakich podmiot może prowadzić określoną działalność,

- zobowiązanie takiego podmiotu do pozbycia się niektórych jego aktywów lub pozycji pozabilansowych ${ }^{30}$.

Rada Gubernatorów FRS może dokonać czynności przygotowania planu organizacji pomocy finansowej oraz menedżerskiej dla nadzorowanej instytucji oraz zatwierdzić natychmiastowe przejęcie już upadłego bądź zagrożonego niewypłacalnością banku przez holding bankowy lub bank stanowy zrzeszony z FRS. Ma też możliwość zainicjowania procedury kontrolowanej likwidacji nadzorowanego podmiotu, w tym celu Rada Gubernatorów FRS ściśle współpracuje zarówno z FDIC, OCC, jak i władzami poszczególnych stanów.

Do 2016 r. Rada uznała za „systemowo ważne” cztery podmioty, tj. American International Group, Inc., Prudential Financial, Inc., MetLife, Inc. oraz GE Capital. Trzeci z wymienionych podmiotów skorzystał z przysługującej mu ścieżki prawnej i w ustawowym czasie odwołał się od decyzji Rady do sądu federalnego dla Dystryktu Kolumbii. W wyroku z marca 2016 r. sąd podzielił stanowisko MetLife, uznając, że Rada nienależycie oszacowała aktualne ryzyka działalności przedsiębiorstwa, ale też konsekwencje ekonomiczne dla MetLife związane z uznaniem tego podmiotu za

29 W tym celu w kwietniu 2012 r. Rada Gubernatorów FRS utworzyła Radę Walidacyjną (Model Validation Council). Do jej zadań należy doradzanie w tworzeniu potencjalnych scenariuszy zagrożeń, reguł przeprowadzania strestestów i następnie odpowiedniej ich oceny przez FRS.

30 Zob. W. Kwiatkowski, op.cit., s. 156. 
systemowo ważny i uchylił decyzję Rady ${ }^{31}$. Z kolei w wypadku ostatniego z wymienionych podmiotów Rada, w czerwcu 2016r., zmieniła swoją własną decyzję w tej materii, uznając, że GE Capital nie jest już systemowo istotnym podmiotem z punktu widzenia stabilności amerykańskiego systemu finansowego.

\section{Federalna Korporacja Ubezpieczająca Depozyty a kontrolowana likwidacja przedsiębiorstwa finansowego}

Do wybuchu kryzysu z 2007 r. federalny ustawodawca przewidywał specjalną, wyłączoną spod federalnego prawa upadłościowego ${ }^{32}$ procedurę likwidacji bądź postawienia w stan upadłości działających na podstawie prawa federalnego banków oraz kas oszczędnościowych. Kluczową rolę w tej procedurze przyznano FDIC. Regulacje te nie korelowały jednak z przeprowadzoną w latach 90 . XX w. deregulacją systemu finansowego w USA, ani $\mathrm{z}$ tym, że procedury określone $\mathrm{w}$ federalnym prawie upadłościowym ${ }^{33}$ nie do końca pasowały do podmiotów mających zadłużenie liczone w dziesiątkach miliardów dolarów i były w dość zawiły sposób powiązane biznesowo z innymi podmiotami. Stąd też ustawą Dodda-Franka rozszerzono zakres tej procedury na towarzystwa ubezpieczeniowe, brokerów giełdowych oraz niebankowe instytucje finansowe objęte dodatkowym nadzorem FRS z mocy ustawy albo uznane przez FSOC za systemowo ważne i z tego tytułu objęte takowym dodatkowym nadzorem.

Obecnie, z inicjatywy sekretarza skarbu bądź na wniosek FRS, FDIC, SEC (w stosunku do brokerów giełdowych) i FIO (w stosunku do firm ubezpieczeniowych) Rada może uznać, że kondycja ${ }^{34}$ bankowej spółki holdingowej o aktywach przekraczających 50 mld USD lub niebankowej instytucji finansowej nadzorowanej

31 MetLife, Inc. v. Financial Stability Oversight Council, C.A. No. 15-0045, D.D.C. Mar. 30, 2016.

32 Zob. S.R. Pellerin, J.R. Walter, Orderly Liquidation Authority as an Alternative to Bankruptcy, „Federal Reserve Bank of Richmond Economic Quarterly” 2012, Vol. 98/1, s. 1-31; M. Saldaña, Parallel Regimes: Bankruptcy and Dodd-Frank's Orderly Liquidation Authority, „Review of Banking \& Financial Law” 2012, s. 531-544.

33 Chodzi tu o działy 11 (reorganizacja) oraz 7 (likwidacja) prawa upadłościowego. Jak pokazało postępowanie w wypadku AIG (dokonano reorganizacji) i Lehman Brothers (dokonano likwidacji), obie procedury okazały się nieefektywne i kosztowne - zarówno dla wierzycieli, jak i budżetu federalnego.

34 Ustawa nie wskazuje tu jasnych kryteriów opartych np. o jakieś matematyczne wskaźniki. Przedsiębiorstwo może być uznane za będące w złej kondycji finansowej (i z tego tytułu zagrażające stabilności sektora finansowego) zasadniczo wtedy, gdy istnieje duże prawdopodobieństwo, że w najbliższym czasie i tak zostałaby w stosunku do niego uruchomiona procedura upadłościowa albo też, że poniosło lub może ponieść straty, które doprowadziłyby do wyczerpania całego (lub zasadniczo całego) jego kapitału i nie ma rozsądnych perspektyw, że tak się nie stanie ani też, że pozyska środki na swą działalność od podmiotów prywatnych. 
przez FRS bądź FDIC stanowi poważne zagrożenie dla stabilności finansowej USA. Sekretarz skarbu musi przy tym skonsultować zasadność uruchomienia procedury z prezydentem, stąd rozstrzygnięcie takie - ingerujące w zasadę swobody działalności gospodarczej - nabiera w pewnym sensie także waloru decyzji politycznej. Jeżeli Rada uzna zasadność wniosku, sekretarz skarbu może umocować Federalną Korporację Ubezpieczającą Depozyty do pełnienia funkcji syndyka, który przeprowadzi procedurę kontrolowanej likwidacji przedsiębiorstwa finansowego (zasadniczo $\mathrm{w}$ wyjątkiem firm ubezpieczeniowych ${ }^{35}$ ). Prawo przewiduje, że w wypadku braku zgody organów zarządzających takim podmiotem na ustanowienie syndyka sekretarz skarbu może wystąpić do sądu dystryktowego dla Dystryktu Kolumbii o wydanie $\mathrm{w}$ postępowaniu tajnym ${ }^{36}$ stosownego zezwolenia na jego ustanowienie (w obu sytuacjach ex lege staje się nim FDIC). Ten jednak może uchylić decyzję Rady jedynie wtedy, gdy stwierdzi, że została ona wydana „arbitralne i kapryśnie” (dosł. arbitrary and capricious) ${ }^{37}$. Nawet jednak wtedy sąd musi uzasadnić swoje rozstrzygnięcie i umożliwić sekretarzowi uzupełnienie dokumentacji bądź przedstawienie nowych dowodów. Warto też nadmienić, że sąd ma na zbadanie sprawy jedynie 24 godziny, a w wypadku przekroczenia tego terminu sekretarz nabywa prawo do ustanowienia FDIC jako syndyka oraz że całe postępowanie wymaga złożenia przez sekretarza (w ciągu 24 godzin od ustanowienia syndyka) raportu komisjom właściwym ds. bankowości i finansów obu izb Kongresu.

Jako syndyk FDIC wchodzi w całokształt praw i obowiązków przedsiębiorstwa, zwłaszcza jej aktywów oraz praw akcjonariuszy i członków kierownictwa przedsiębiorstwa. Wykonując swoje zadania w tej materii, FDIC musi mieć na uwadze trzy kwestie. Po pierwsze, musi dążyć do zachowania stabilności finansowej poprzez utrzymanie ciągłości działania podmiotu w kluczowych kwestiach i umożliwić mu realizację płatności zobowiązań „systemowo krytycznych”. Po drugie, jego działania muszą być nakierowane na minimalizację strat wierzycieli oraz na to, by wierzyciele

35 Odstępstwa od tej procedury dotyczą towarzystw ubezpieczeniowych. Do ich likwidacji upoważnione są bowiem stosowne podmioty stanowe. Jednakże w sytuacji, w której stosowny stanowy organ nie uruchomi skutecznie procedury likwidacji (ma na to 60 dni od uznania przez FSOC, że podmiot ten zagraża stabilności systemu finansowego USA), może ją przeprowadzić FDIC (na zasadach określonych w prawie tego stanu).

36 Ta oraz kilka innych kwestii budzi poważne zastrzeżenia co do ich zgodności z konstytucją. Zob. T.W. Merrill, M.L. Merrill, Dodd-Frank Orderly Liquidation Authority: Too Big for the Constitution?, „University of Pennsylvania Law Review" 2014, No. 165, s. 204-230. Materiał dostępny na stronie: http://scholarship. law.upenn.edu/cgi/viewcontent.cgi?article=9461\&context=penn_law_review [dostęp 12.10.2016]

37 Zob. E.V. Murphy, M.B. Bernier, Financial Stability Oversight Council: A Framework to Mitigate Systemic Risk, CRS Report to Congress, Washington 2011, s. 17. Materiał dostępny na stronie: https://opencrs. com/document/R42083/ [dostęp 12.10.2016] 
byli zaspokajani zgodnie z regułami określonymi w przepisach prawa ${ }^{38}$. Po trzecie, FDIC musi działać tak, by nie doszło do sytuacji, w której do ratowania podmiotu prywatnego zaangażowano by środki publiczne.

W odróżnieniu od reguł przewidzianych w federalnym prawie upadłościowym rola sądów upadłościowych jest tu marginalna, FDIC ma prawo do uznania bądź odmowy uznania konkretnych roszczeń, a wierzyciel kwestionujący takowe rozstrzygnięcie może wówczas jedynie złożyć pozew skarżący tę decyzję w sądzie federalnym właściwym dla siedziby likwidowanego przedsiębiorstwa. Jako syndyk korporacja może odrzucić wcześniej ustalone przez likwidowane przedsiębiorstwo warunki konkretnych umów, bądź wypowiedzieć takowe wówczas, gdy uzna, że ich zawarcie lub ( $w$ wypadku już zawartych) kontynuacja jest zbyt uciążliwa lub nieefektywna, a - z kilkoma wyjątkami - stronom zawartych już umów przysługuje roszczenie jedynie w granicach damnum emergens. FDIC ma też możliwość negocjowania zasad przejęcia przedsiębiorstwa przez inny podmiot (bądź podmioty) albo zbywania wybranych składników aktywów likwidowanego przedsiębiorstwa wybranym przez siebie podmiotom czy tworzonej w tym celu spółce pomostowej (tzw. bridge financial company) - mając na uwadze maksymalne dochody z ich sprzedaży, ale też stabilność systemu finansowego. Nie musi przy tym informować o tym prywatnych wierzycieli, udziałowców czy stron umów zawartych wcześniej przez przedsiębiorstwo podlegające likwidacji. Warto też dodać, że zgodnie z ustawą ostatecznych kosztów likwidacji takiej instytucji (tj. wówczas, gdy nie da się ich pokryć z aktywów likwidowanego przedsiębiorstwa) nie ponosi budżet federalny, lecz specjalny fundusz likwidacyjny (zarządzany przez FDIC), którego udziałowcami mają być największe instytucje finansowe w USA.

Na zakończenie warto nadmienić, że procedura kontrolowanej likwidacji nie została dotychczas wykorzystana w praktyce. Mechanizm ten jest jednak postrzegany jako skuteczne narzędzie dyscyplinujące podmioty dotychczas uznawane za „zbyt duże, by pozwolono im upaść" (chodzi tu zwłaszcza o niebankowe instytucje finansowe).

\section{Podsumowanie}

Działania legislacyjne podjęte po wybuchu kryzysu z 2007 r. można uznać za próbę uchylenia się federalnych ośrodków władzy od bezpośredniego podejmowania decyzji koniecznych do prawidłowego funkcjonowania państwa, ale z wielu powodów

3811 U.S. Code $\$ 507$. Zob. także: S.R. Pellerin, J.R. Walter, op.cit., s. 10. 
„niewygodnych” politycznie. Nie ulega jednak wątpliwości, że powołanie do życia FSOC jest krokiem w dobrą stronę, mającym na celu załatanie luk w nadzorze nad złożonym systemem finansowym w USA, zwłaszcza po deregulacji sektora dokonanej w latach 90. XX w. Jest to także słuszna decyzja w kontekście coraz to nowych wyzwań, jakie stoją przed Stanami Zjednoczonymi w zakresie zapewnienia stabilności systemu finansowego. Za szczególnie pozytywne należy też uznać to, że po raz pierwszy ustawodawca federalny dość skutecznie powiązał z organami federalnymi (w sposób nienaruszający autonomii stanów w ramach federalizmu amerykańskiego) stanowe organy wykonujące nadzór nad podmiotami działającymi jedynie na podstawie prawa stanowego.

Mając na uwadze niespełna sześć lat, jakie minęły od wejścia w życie ustawy, trudno udzielić jasnej odpowiedzi co do tego, na ile mechanizmy w niej przewidziane okazały się skuteczne. Czytając raporty zamieszczone na stronie Departamentu Skarbu ${ }^{39}$, można dojść do wniosku, że objęcie wspomnianych wcześniej kilku podmiotów wzmożonym nadzorem było posunięciem słusznym, a orzeczenie sądu federalnego w sprawie MetLife dało jasno do zrozumienia, że sądowa kontrola rozstrzygnięć FSOC nie jest - wbrew temu, co podnoszono w trakcie prac nad projektem ustawy - fikcją. Z kolei w wypadku postępowania w ramach procedury kontrolowanej likwidacji szczegółowe procedury zostały określone przez Radę FDIC i inne współodpowiedzialne podmioty, ale $-\mathrm{z}$ uwagi na to, że nie wystąpiło określone ryzyko - mechanizmy te nie były dotychczas wykorzystane w praktyce. Bez wątpienia jednak procedura kontrolowanej likwidacji jest postrzegana jako skuteczne narzędzie dyscyplinujące podmioty dotychczas uznawane za „zbyt duże, by pozwolono im upaść" (zwłaszcza w kontekście niebankowych instytucji finansowych).

\section{Bibliografia}

Bank Holding Company Act 1956, Pub. L. 84-511.

Banking Act, Glass-Steagall Act 1933, Pub. L. 73-66.

Bernanke B.S., The Courage to Act: A Memoir of a Crisis and Its Aftermath, W.W. Norton \& Company, New York 2015.

Dam K.W., The Subprime Crisis and Financial Regulation: International and Comparative Perspectives, „John M. Olin Law \& Economics Working Paper” 2010, No. 517.

Dodd-Frank Wall Street Reform and Consumer Protection Act of 2010, Pub. L. 111-203.

39 Zob. https://www.treasury.gov/initiatives/fsoc/designations/Pages/default.aspx [dostęp 11.10.2016]. 
Financial Services Modernization Act of 1999, Pub. L.106-102.

Financial Stability Oversight Council Annual Report 2012, Washington 2012.

Kwiatkowski W., System Rezerwy Federalnej, Wydawnictwo Naukowe Scholar, Warszawa 2014.

Merrill T.W., Merrill M.L., Dodd-Frank Orderly Liquidation Authority: Too Big for the Constitution?, „University of Pennsylvania Law Review” 2014, No. 165.

MetLife, Inc. v. Financial Stability Oversight Council, C.A. Nr 15-0045, D.D.C. Mar. 30, 2016.

Mika A., Przedkryzysowa architektura nadzorczo-regulacyjna w USA jako katalizator kryzysu subprime, „Bezpieczny Bank” 2012, nr 4(49).

Mishkin F., Ekonomika pieniądza, bankowości i rynków finansowych, PWN, Warszawa 2002.

Murphy E.V., Bernier M.B., Financial Stability Oversight Council: A Framework to Mitigate Systemic Risk, CRS Report to Congress, Washington 2011.

Pellerin S.R., Walter J.R., Orderly Liquidation Authority as an Alternative to Bankruptcy, „Federal Reserve Bank of Richmond Economic Quarterly” 2012, Vol. 98/1.

Riegle-Neal Act Interstate Banking and Branching Efficiency Act of 1994, Pub. L. 103-328.

Saldaña M., Parallel Regimes: Bankruptcy and Dodd-Frank's Orderly Liquidation Authority, „Review of Banking \& Financial Law” 2012.

Sławiński A., Przyczyny globalnego kryzysu bankowego, w: Nauki społeczne wobec kryzysu na rynkach finansowych, red. J. Osiński, S. Sztaba, Oficyna Wydawnicza SGH, Warszawa 2009.

\section{Financial stability oversight council: its position in the US government and goals}

Present article discusses some of the key issues introduced to the US federal law in 2010 to ensure the stability of the financial sector in the United States. Special attention was paid to two issues, i.e. the rules and procedures under which the FSOC may considered a non-banking finance company to be important from the point of view of stability of the US financial sector (and in such situation trigger supplementary supervision by the FRS) and the procedure for controlled liquidation of a financial company considered by the FSOC to be a risk to the stability of the US financial system.

Keywords: systemic risk, bankruptcy, United States, financial system, Dodd-Frank Act 


\section{Position dans le système du pouvoir des etats-unis et les taches du conseil de surveillance de la stabilité financière}

Larticle analyse certaines solutions-clé introduites dans la loi fédérale des Etats-Unis en 2010 et ayant pour but d'assurer une plus grande stabilité du secteur financier aux USA. Deux questions ont été examinées de façon plus profonde, notamment les principes et procédures selon lesquels le Conseil de surveillance de la stabilité financière peut considérer une entreprise financière non-bancaire comme importante du point de vue de la stabilité du secteur financier des Etats-Unis (et à ce titre l'inclure à la surveillance de la banque centrale), ainsi que la procédure de liquidation contrôlée de l'entreprise financière laquelle, selon le Conseil, pourrait déstabiliser le système financier des USA.

Mots-clés: risque systémique, faillite, Etats-Unis, système financier, loi de Dodd-Frank

\section{Совет по надзору за финансовой стабильностью: положение В системе органов государственной власти США и его задачи}

В статье рассматриваются некоторые из ключевых изменений, внесенных в федеральный закон США в 2010 году для обеспечения стабильности финансового сектора в Соединенных Штатах. Особое внимание было уделено двум вопросам, т. е. правилам и процедурам, на основе которых Совет по надзору за финансовой стабильностью может считать небанковскую финансовую компанию важной с точки зрения устойчивости финансового сектора в США (и осуществить в ее отношении дополнительный надзор со стороны центрального банка), и процедуру контролируемой ликвидации финансовой компании, признанной Советом угрожающей стабильности финансовой системы США.

Ключевые слова: системный риск, банкротство, США, финансовая система, закон Додда-Франка 